\begin{tabular}{|c|c|c|c|}
\hline $\begin{array}{c}\text { A } \\
\text { REVIEW }\end{array}$ & $\begin{array}{r}\text { ADVANCE RESEARC } \\
\text { Volume } 9 \mid \text { Issue } 1 \mid\end{array}$ & $\begin{array}{l}\text { OCIAL SCIENCE } \\
231-6418\end{array}$ & \\
\hline $0=$ & DOI: 10.15740/HAS/ARJSS/9.1/114-118 & Visit us : www.researchjournal.co.in & \\
\hline
\end{tabular}

\title{
Life skill education in school for sustainable human development
}

Sampreety Gogoi

Department of Human Development and Families Studies, College of Community Science, Assam Agricultural University, Jorhat (Assam) India

(Email : sampreetygogoi@gmail.com)

\section{ARTICLE INFO :}

Received : 05.02 .2018

Accepted : $\quad 25.05 .2018$

KEY WORDS :

Life skill, Sustainable, Human development

HOW TO CITE THIS ARTICLE :

Gogoi, Sampreety (2018). Life skill education in school for sustainable human development. Adv. Res. J. Soc. Sci., 9 (1)

: 114-118, DOI: 10.15740/HAS/ARJSS/ 9.1/114-118.

Copyright@2018 : Hind Agri -

Horticultural Society

\begin{abstract}
Young people are faced by many challenges because of fast changing world. The challenges are compounded by various factors such as complex developmental changes during adolescence, lack of positive role models, negative mass media influence and inadequate, inaccurate and sometimes unreliable sources of information. As a result, many children engage in antisocial behaviour. Young people today are growing up with an increasing sense of suspicion and gloom. Their mind is concluded by anxiety and trepidation about their future, academic and career. Low self-esteem and lack of effective skill can lessen students desire to learn, their ability to focus, and their willingness to take risks. Life skills "can help people to make informed decisions, communicate effectively and develop coping and self-management skills that may help an individual to lead a healthy and productive life." These skills are to be taught to adolescents in schools, as they can help them in successfully transition from childhood to adulthood by healthy development of social and emotional skills. Life skills training in schools must meet the social and emotional developmental needs of students for effective teaching and learning to take place and for students to reach their full potential. Life skills training is an efficacious tool for empowering the youth to act responsibly, take initiative and take control. It is based on the assumption that when young people are able to rise above emotional impasses arising from daily conflicts, entangled relationships and peer pressure, they are less likely to resort to anti social or high risk behaviors and finally leads to sustainable human development.
\end{abstract}

